\title{
Serum high mobility group box protein 1 as a clinical marker for ovarian cancer
}

\author{
Y. LI ${ }^{\ddagger}$, J. TIAN ${ }^{\ddagger}$, X. FU, Y. CHEN, W. ZHANG, H. YAO, Q. HAO*
}

Tianjin medical university cancer institute and hospital, National Clinical Research Center of Cancer, Huan-Hu-Xi Road, Ti-Yuan-Bei, He Xi District, Tianjin, 300060 China

*Correspondence: haoquandoctor@126.com

${ }^{*}$ Contributed equally to this work.

\section{Received October 1, 2013 / Accepted January 28, 2014}

\begin{abstract}
The aim of the study was to evaluate the clinical value of serum high mobility group box chromosomal protein 1 (HMGB1) in ovarian cancer and analyze the correlation between HMGB1 and ovarian cancer clinicopathologic outcomes.

A total of 105 patients with diagnosed epithelial ovarian cancer, 46 patients with ovarian benign disease and 33 healthy volunteers were enrolled from January 2011 through January 2013. Serum HMGB1 levels were analyzed by enzyme-linked immunosorbent assay.

The mean value of serum HMGB1 levels in ovarian cancer patients $(78.18 \pm 54.87 \mathrm{ng} / \mathrm{ml})$ was significantly higher than those in benign patients $(33.98 \pm 9.97 \mathrm{ng} / \mathrm{ml})$ and healthy control $(26.71 \pm 7.99 \mathrm{ng} / \mathrm{ml}, \mathrm{p}<0.0001)$, respectively. The serum HMGB1 levels were $40.33 \pm 6.50 \mathrm{ng} / \mathrm{ml}, 61.16 \pm 20.15 \mathrm{ng} / \mathrm{ml}, 81.81 \pm 51.15 \mathrm{ng} / \mathrm{ml}$ and $119.48 \pm 84.28 \mathrm{ng} / \mathrm{ml}$ in patients with TNM stage I, II, III, and IV, respectively ( $<<0.0001$ ). There were 81 of the 105 ovarian cancer patients obtained complete remission, the serum HMGB1 levels before treatment $(71.99 \pm 42.49 \mathrm{ng} / \mathrm{ml})$ were much higher than that at remission stage $(42.10 \pm 15.48 \mathrm{ng} / \mathrm{ml})$ $(\mathrm{p}<0.0001)$. During our investigating period, 28 ovarian cancer patients underwent recurrence, the serum HMGB1 levels were $75.54 \pm 39.50 \mathrm{ng} / \mathrm{ml}$ in these recurrent ovarian cancer patients compared to $42.04 \pm 10.68 \mathrm{ng} / \mathrm{ml}$ in non-recurrent ovarian cancer $(\mathrm{p}<0.0001)$. None of the remission or recurrent patients came from benign ovarian tumor group.

Our study suggests that HMGB1 may be a useful clinical marker for evaluating progression and predicting prognosis of ovarian carcinoma. Targeting HMGB1 production or release might have potential approaches for ovarian carcinoma treatment.
\end{abstract}

Key words: high mobility group box chromosomal protein 1, ovarian cancer, prognosis

Ovarian cancer is one of the most lethal gynecologic malignancies with rapid progression and poor survival. Primarily due to asymptomatic presentation and lacking of highly sensitive biomarkers for early detection, women continue to be diagnosed with advanced-stage disease. Despite substantial advances in ovarian cancer research and improvements in treatments, survival to incidence ratio is still poor and overall cure rate remains very low [1]. For further insights into the treatment of ovarian cancer, we need to find new tools for early detection and to study the molecular biology that characterises ovarian cancer cells.

HMGB1 is a non-histone, chromatin-binding nuclear protein which has a highly conserved sequence among various species with $98 \%$ identity between rodent, bovine and human proteins[2]. HMGB1 appears to have two distinct functions in cellular systems. In nucleus, HMGB1 can bind chromatin, stabilize nucleosome and regulate transcription[3], while secreted outside cells, it acts as an extracellular signaling molecule[4]. Some recent studies indicated that HMGB1 regulates the transcription of many cancer genes, such as Eselectin, TNF- $\alpha$, insulin receptor, and BRCA1 [5-7], suggested an important relationship between HMGB1 and cancer. By present, many researches confirmed the facilitating effect of HMGB1 on tumor, for example, HMGB1 has been reported to be increased in colorectal cancer [8], nasopharyngeal cancer[9], lung cancer[10], gastric cancer[11] and so on, indicating HMGB1 as an important mediator for cancer transformation, proliferation and invasion.

By present, there have been some achievements demonstrated the facilitating effects of HMGB1 on ovarian cancer[12]. However, the relationship between serum HMGB1 and ovarian cancer disease progression have not been evaluated. In this study, 
we measured the serum levels of HMGB1 by ELISA, analyzed relationship between HMGB1 and ovarian cancer patients' clinic pathological parameters, therapy efficacy, and recrudescence.

\section{Patients and methods}

Patients. A total of 105 patients with diagnosed epithelial ovarian cancer, 46 patients with diagnosed benign ovarian tumor and 30 healthy volunteers were enrolled from January 2011 through January 2013 at department of Gynecological Cancer, Tianjin medical university cancer institute and hospital. The present study and the experiments were approved by the ethics committee of the Tianjin medical university cancer institute and hospital, and all the volunteers and patients gave written informed consent prior to participation. All of the ovarian cancer patients were clinically staged according to the FIGO staging system. The control subjects are free from significant disease, prior tumor illness, trauma/fracture, inflammatory systemic disease or infection, rheumatologic disease, stroke, vascular or other internal medical condition. All cancer patients were diagnosed for the first time during the enrollment period and their blood samples were collected before they received any treatment such as surgery, chemotherapy or radiotherapy. Among all of the malignant ovarian tumor patients enrolled in our investigation, 81 patients obtained disease remission whose serum HMGB1 levels were measured before treatment and at remission. Furthermore, there were 28 ovarian cancer patients underwent recurrence during the study period, and their serum HMGB1 levels were measured after recurrence. The clinic pathologic characteristics of patients were in Table 1 .

HMGB1 measurements. Approximately $10 \mathrm{ml}$ of whole blood was collected in non-heparinized tubes from each fasting

Table 1. Baseline characteristics of the ovarian cancer patients.

\begin{tabular}{lccc}
\hline Variables & N(\%) & $\begin{array}{c}\text { HMGB1 } \\
(\mathrm{ng} / \mathrm{ml})\end{array}$ & $\mathbf{P}$ \\
mean \pm SD & \\
\hline Age & $36(34.3)$ & $76.19 \pm 25.02$ & \\
$\quad<50$ & $69(65.7)$ & $79.22 \pm 59.89$ & \\
$\quad>50$ & & & 0.728 \\
Pathology type & $48(45.7)$ & $74.67 \pm 43.95$ & \\
$\quad$ Serous cystadenocarcinoma & $39(37.1)$ & $79.81 \pm 66.05$ & \\
$\quad$ Endometrioid carcinoma & $18(17.1)$ & $84.59 \pm 57.07$ & \\
$\quad$ Mucinous cystadenocarcinoma & & $<0.001$ \\
Tumor stage & $12(11.4)$ & $40.33 \pm 6.50$ & \\
$\quad$ stage I & $29(27.6) /$ & $61.16 \pm 20.15$ & \\
$\quad$ stage II & $45(42.9)$ & $81.81 \pm 51.15$ & \\
$\quad$ stage III & $19(18.1)$ & $119.48 \pm 84.28$ & \\
$\quad$ stage IV & & & 0.002 \\
Distance metastasis & $86(81.9)$ & $68.97 \pm 41.40$ & \\
$\quad$ Non-metastasis & $19(18.1)$ & $119.89 \pm 84.13$ & \\
$\quad$ Metastasis & & & \\
\hline
\end{tabular}

subject and allowed to clot at room temperature for half an hour, then centrifuged at $1,000 \times \mathrm{g}$ for $15 \mathrm{~min}$, and serum collected for storage at $-80^{\circ} \mathrm{C}$ in microfuge tubes until assayed. HMGB1 was measured by the commercially available HMGB1 ELISA Kit II (SHINO-TEST Corporations, Kanagawa, Japan). Briefly, $100 \mu \mathrm{l}$ of sample diluent was added to each well and then $10 \mu \mathrm{l}$ of standard, sample or control was added to the well. Then the microtiter plates were incubated for $20-24 \mathrm{~h}$ at $37^{\circ} \mathrm{C}$. After 5

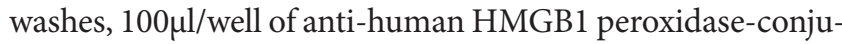
gated monoclonal anti-body was added and incubated at room temperature for $2 \mathrm{~h}$. After 5 washes, the chromogen 3,3,5,5'tetra-methylbenzidine was added to each well. After reacting for $30 \mathrm{~min}$ at room temperature, the chromogenic substrate reaction was stopped by the addition of stop solution and the absorbance was read at $450 \mathrm{~nm}$. The results were calculated using a calibration curve prepared from standards.

Statistical analysis. The results were expressed as the mean \pm standard deviation. One-way analysis of variance (ANOVA) with post-hoc Bon-ferroni adjustment for pairwise comparison was used to compare the means of HMGB1 among groups. Pearson correlation analysis was performed to assess the correlations between HMGB1 and the continuous variables, and Spearman correlation was performed to assess the correlations between HMGB1 and the non-continuous variables. Statistical Package for Social Sciences software (SPSS, Chicago, Illinois, USA version 17.0) was used for data support and analysis and p-values $<0.05$ were considered as statistically significant differences.

\section{Results}

Serum HMGB1 levels in ovarian cancer patients, ovarian benign tumor patients and healthy control. The mean value of serum HMGB1 levels in 105 patients with ovarian cancer was $78.18 \pm 54.87 \mathrm{ng} / \mathrm{ml}$ and was significantly higher than those in 46 ovarian benign tumor patients $(33.98 \pm 9.97 \mathrm{ng} / \mathrm{ml})$, and 30 healthy control $(26.71 \pm 7.99 \mathrm{ng} / \mathrm{ml}, \mathrm{p}<0.0001$, respectively, Fig. 1). The serum HMGB1 levels in ovarian benign tumor patients were higher than those in healthy, but there was no statistical significance between them.

The serum HMGB1 levels in patients with different tumor stage of ovarian cancer. The tumor stage was defined by the FIGO staging (TNM stage) for ovarian cancer to evaluate whether HMGB1 was associated with ovarian cancer metastases to lymph nodes, distant organs, vascular invasion and tumor characteristics. The serum HMGB1 levels were $40.33 \pm 6.50 \mathrm{ng} / \mathrm{ml}, 61.16 \pm 20.15 \mathrm{ng} / \mathrm{ml}, 81.81 \pm 51.15 \mathrm{ng} / \mathrm{ml}$ and $119.48 \pm 84.28 \mathrm{ng} / \mathrm{ml}$ in patients with TNM stage I, II, III, and IV. There were significant differences among four groups and between two groups (Fig. 2).

The serum HMGB1 levels in patients with ovarian cancer before treatment and at remission stage. To determine whether the serum HMGB1 level was associated with clinical treatment, we measured the serum HMGB1 levels of the same patients before treatment and after complete remission. 


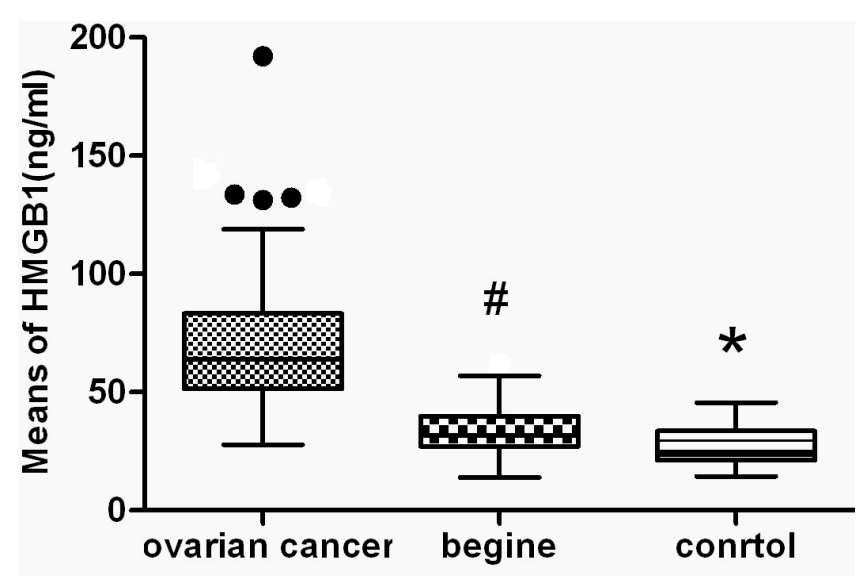

Figure 1. Serum levels of HMGB1 levels in patients with ovarian cancer *, \# Significantly lower versus ovarian cancer $(\mathrm{p}<0.0001$, respectively).

The serum HMGB1 levels were $71.99 \pm 42.49 \mathrm{ng} / \mathrm{ml}$ in patients before therapy, and $42.10 \pm 15.48 \mathrm{ng} / \mathrm{ml}$ after remission $(\mathrm{p}<0.0001)$ (Fig. 3).

The serum HMGB1 levels in patients with recurrent ovarian cancer and non-recurrent ovarian cancer. To determine whether the serum HMGB1 level was associated with ovarian cancer progression and recurrence, we compared the serum HMGB1 levels in recurrent ovarian cancer patients during the study period with the non-recurrent patients. Serum HMGB1 levels in patients with recurrent ovarian cancer $(75.54 \pm 39.50$ $\mathrm{ng} / \mathrm{ml}$ ) were significantly higher than in patients with nonrecurrent disease ( $42.04 \pm 10.68 \mathrm{ng} / \mathrm{ml})$ (Fig. 4).

\section{Discussion}

In this study, we evaluated serum HMGB1 concentrations in 105 patients with ovarian carcinoma and compared them to

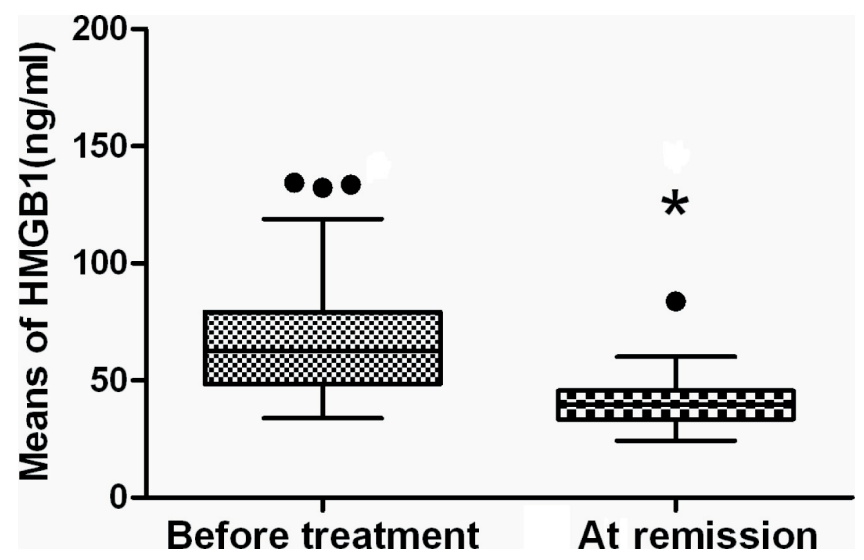

Figure 3. Serum levels of HMGB1 in patients with ovarian cancer before treatment and after remission

${ }^{\star}$ Significantly lower versus before treatment $(\mathrm{p}<0.0001)$.

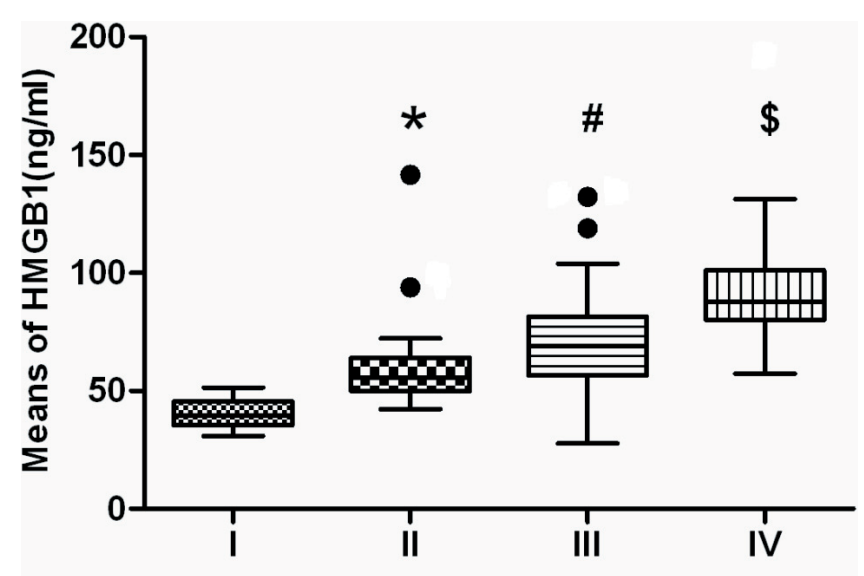

Tumor stages

Figure 2. Serum levels of HMGB1 in patients with tumors of different stage Value among four groups was significantly different $(p<0.0001)$; ${ }^{*}$ versus stage I group, $p<0.01$; \# versus stage II group, $p<0.01$; $\$$ versus stage III group, $\mathrm{p}<\mathbf{0 . 0 1}$.

the concentrations in benign ovarian tumors and healthy control subjects. Analysis of serum HMGB1 levels revealed that HMGB1 was overexpressed in malignant ovarian tumors and associated with high stage and distant metastasis. These results indicated that HMGB1 may play a pivotal role in the development of ovarian cancer. However, HMGB1 was unassociated with patient ages and pathology types of ovarian carcinoma, suggested that HMGB1 was not affected by tissue histologic type. These results are consistent with those of Jie Chen et al. in which HMGB1 was evaluated in ovarian cancer tissue[13]. Numerous reports indicated that the serum HMGB1 level was elevated in patients with various types of cancer. Hanna Lee et al. showed that the serum HMGB1 level was increased by 1.5fold in patients with colorectal carcinoma compared to those

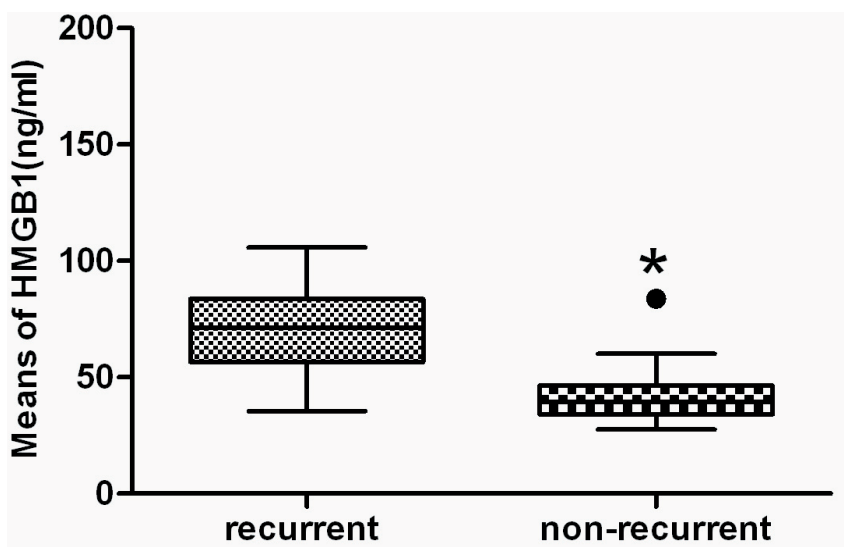

Figure 4. Serum levels of HMGB1 in patients with recurrent ovarian cancer and non-recurrent ovarian cancer

${ }^{\star}$ Significantly lower versus recurrent ovarian cancer $(\mathrm{p}<0.0001)$. 
in healthy control[14]. HMGB1 is also closely associated with the clinical and pathologic features of gastric cancer[11]

To our knowledge, this report demonstrated for the first time that ovarian cancer patients' serum HMGB1 level dropped significantly after the developing remission of the disease. Moreover, the patients who underwent recrudescence had a higher serum HMGB1 level compared with the non-recurrent patients. This relatively new discovery might provide insight that HMGB1 may play an important role not only in development of ovarian cancer but also in poor outcome of ovarian cancer patients. Similar results have been indicated by Xiugui Sheng and his colleagues that serum HMGB1 level could be a useful marker for evaluating the disease recurrence and predicting prognosis in patients with cervical squamous cell carcinomas[15].

Several factors may contribute to elevation in serum HMGB1 levels in the patients with ovarian cancer. One is that HMGB1 can be passively released from dying ovarian tumor cells. Tumor cells proliferation may outpace the rate of angiogenesis, resulting in tissue severe ischeamic hypoxia[16] . It is well known that HMGB1 can be passively released by necrotic and ischeamic cells $[17,18]$. Considered these results together, HMGB1 release through tumor cell death might contribute to the elevation of serum HMGB1 levels. On the other hand; it was well known that HMGB1 can be actively released from immune cells into the extra-cellular space or serum[19]. HMGB1 was known to be important in malignant cell transformation. As reported by Poser I and his colleagues, HMGB1 leads to malignant transformation and melanoma development [20]. Recent researches have shown that HMGB1 overexpression can improve proliferation[21] and decrease drug sensitivity of cancer cell[22]. In addition, HMGB1 functions as an antiapoptotic oncoprotein by activating NF- $\mathrm{kB}$ and the apoptosis inhibitor c-IAP [23]. Moreover, a variety of agents such as cancer chemotherapeutic agents, oncolytic viruses, ultraviolet or gamma irradiation, cytolytic $T$ and nature killer cells that leading to tumor cell death can indicate classic apoptosis markers that were associated with HMGB1 release[24]. These reports suggest that HMGB1 could be an oncoprotein for contribution to the tumor development and formation.

Post-translational modification has also significant effects on HMGB1. Compared to the nonmodified proteins, acetylated HMGB-1 exhibited both stronger binding to linker DNA-containing nucleosomes and a higher co-remodeling activity[25]. The acetylated protein was 3 -fold more effective in inducing ligase-mediated circularization of a 111-bp DNA fragment[26]. Researchers has also found that acetylation is critical for active HMGB1 release[27]. In addition, acetylation affects HMGB1 to promote inflammation and determine its role in inflammation and immunity[28]. It is well known that chronic inflammation is an important tumor promoter. Considering these together, acetylation of HMGB1 may contribute to the development of malignancies. However, there has been no direct evidence about the relationship between the HMGB1 acetylation and cancer progression.
Extracellular HMGB1 transduse cellular signals by interacting with at least three receptors: RAGE, TLR2 and TLR4. Researchers showed that malignant cells and immature cells express high levels of HMGB1 and RAGE[29]. Furthermore, RAGE was found in 19\%, $81 \%$ and $100 \%$ of Dukes' B, C and $D$ cases, respectively, correlating with invasiveness and poor prognosis[30]. HMGB1/RAGE signaling pathways activate nuclear factor- $\kappa \mathrm{B}(\mathrm{NF}-\kappa \mathrm{B})$ pathway, mitogen activated protein kinase (MAPK) and type IV collagenase (MMP-2/MMP9), cause extracellular matrix degradation and tumor cells metastasis.[31] Recent research indicated that knockdown of HMGB1 in gastric cancer can inhibit cell migration and invasion, induce cell apoptosis and decrease MMP-9 expression[32].

In solid tumors, necrosis is commonly found in the core region in response of oxygen and glucose deletion because rapid growth of tumors may outpace the rate of angiogenesis, resulting in tissue severe ischemic hypoxia. HMGB1 released from necrotic tumor cells will function as a proinflammatory cytokine to create a microenvironment which is similar to chronic inflammation and in return contribute to the development of epithelial malignancies[33].

\section{Conclusion}

The results of our study showed that HMGB1 is overexpressed in ovarian cancer and related with clinical treatment and disease outcome, indicating that blocking of HMGB1 production or release, or preventing its interaction with its receptor(s) might provide an important opportunity for the prevention or treatment of ovarian cancer. Therefore, further studies are needed to reach on a deeper understanding of the biology of HMGB1 in ovarian cancer and to evaluate its therapeutic usefulness.

Acknowledgments: This study was supported by a Natural Science Foundation (12JCYBJC17000) from Tianjin Science and Technology Commission and a National Natural Science Foundation of China (30901742).

\section{References}

[1] BAST RJ, HENNESSY B, MILLS GB. The biology of ovarian cancer: new opportunities for translation. Nat Rev Cancer 2009; 9: 415-28. http://dx.doi.org/10.1038/nrc2644

[2] YOTOV WV, ST-ARNAUD R. Nucleotide sequence of a mouse cDNA encoding the nonhistone chromosomal high mobility group protein-1 (HMG1). Nucleic Acids Res 1992; 20: 3516. http://dx.doi.org/10.1093/nar/20.13.3516

[3] LOTZE MT, TRACEY KJ. High-mobility group box 1 protein (HMGB1): nuclear weapon in the immune arsenal. Nat Rev Immunol 2005; 5: 331-42. http://dx.doi.org/10.1038/ $\underline{\text { nri1594 }}$

[4] MULLER S, SCAFFIDI P, DEGRYSE B, BONALDI T, RONFANI L, et al. New EMBO members' review: the double life of HMGB1 chromatin protein: architectural factor and 
extracellular signal. Embo J 2001; 20: 4337-40. http://dx.doi. org/10.1093/emboj/20.16.4337

[5] THANOS D, MANIATIS T. The high mobility group protein HMG I(Y) is required for NF-kappa B-dependent virus induction of the human IFN-beta gene. Cell 1992; 71: 777-89. http://dx.doi.org/10.1016/0092-8674(92)90554-P

[6] BALDASSARRE G, BATTISTA S, BELLETTI B, THAKUR S, PENTIMALLI F, et al. Negative regulation of BRCA1 gene expression by HMGA1 proteins accounts for the reduced BRCA1 protein levels in sporadic breast carcinoma. Mol Cell Biol 2003; 23: 2225-38. http://dx.doi.org/10.1128/MCB.23.7.2225$\underline{2238.2003}$

[7] FASHENA SJ, REEVES R, RUDDLE NH. A poly(dA-dT) upstream activating sequence binds high-mobility group I protein and contributes to lymphotoxin (tumor necrosis factor-beta) gene regulation. Mol Cell Biol 1992; 12: 894-903.

[8] YAO X, ZHAO G, YANG H, HONG X, BIE L, et al. Overexpression of high-mobility group box 1 correlates with tumor progression and poor prognosis in human colorectal carcinoma. J Cancer Res Clin Oncol 2010; 136: 677-84. http://dx.doi. org/10.1007/s00432-009-0706-1

[9] WU D, DING Y, WANG S, ZHANG Q, LIU L. Increased expression of high mobility group box 1 (HMGB1) is associated with progression and poor prognosis in human nasopharyngeal carcinoma. J Pathol 2008; 216: 167-75. http://dx.doi. org/10.1002/path.2391

[10] LIU PL, TSAI JR, HWANG JJ, CHOU SH, CHENG YJ, et al. High-mobility group box 1-mediated matrix metalloproteinase-9 expression in non-small cell lung cancer contributes to tumor cell invasiveness. Am J Respir Cell Mol Biol 2010; 43: 530-38. http://dx.doi.org/10.1165/rcmb.2009-0269OC

[11] CHUNG HW, LEE SG, KIM H, HONG DJ, CHUNG JB, et al. Serum high mobility group box-1 (HMGB1) is closely associated with the clinical and pathologic features of gastric cancer. J Transl Med 2009; 7: 38. http://dx.doi.org/10.1186/1479-58767-38

[12] CHEN J, LIU X, ZHANG J, ZHAO Y. Targeting HMGB1 inhibits ovarian cancer growth and metastasis by lentivirusmediated RNA interference. J Cell Physiol 2012; 227: 3629-38. http://dx.doi.org/10.1002/jcp.24069

[13] CHEN J, XI B, ZHAO Y, YU Y, ZHANG J, et al. High-mobility group protein $\mathrm{B} 1$ (HMGB1) is a novel biomarker for human ovarian cancer. Gynecol Oncol 2012; 126: 109-17. http://dx.doi.org/10.1016/j.ygyno.2012.03.051

[14] LEE H, SONG M, SHIN N, SHIN CH, MIN BS, et al. Diagnostic significance of serum HMGB1 in colorectal carcinomas. PLoS One 2012; 7: e34318. http://dx.doi.org/10.1371/journal. pone.0034318

[15] SHENG X, DU X, ZHANG X, LI D, LU C, et al. Clinical value of serum HMGB1 levels in early detection of recurrent squamous cell carcinoma of uterine cervix: comparison with serum SCCA, CYFRA21-1, and CEA levels. Croat Med J 2009; 50: 455-64. http://dx.doi.org/10.3325/cmj.2009.50.455

[16] CARMELiET P. Angiogenesis in life, disease and medicine. Nature 2005; 438: 932-36. http://dx.doi.org/ $\underline{10.1038 / \text { nature } 04478}$
[17] ROVERE-QUERINI P, CAPOBIANCO A, SCAFFIDI P, VALENTINIS B, CATALANOTTI F, et al. HMGB1 is an endogenous immune adjuvant released by necrotic cells. Embo Rep 2004; 5: 825-30. http://dx.doi.org/10.1038/ sj.embor.7400205

[18] SCAFFIDI P, MISTELI T, BIANCHI ME. Release of chromatin protein HMGB1 by necrotic cells triggers inflammation. Nature 2002; 418: 191-95. http://dx.doi. org/10.1038/nature00858

[19] CHENG BQ, JIA CQ, LIU CT, LU XF, ZHONG N, et al. Serum high mobility group box chromosomal protein 1 is associated with clinicopathologic features in patients with hepatocellular carcinoma. Dig Liver Dis 2008; 40: 446-52. http://dx.doi. org/10.1016/j.dld.2007.11.024

[20] POSER I, GOLOB M, BUETTNER R, BOSSERHOFF AK. Upregulation of HMG1 leads to melanoma inhibitory activity expression in malignant melanoma cells and contributes to their malignancy phenotype. Mol Cell Biol 2003; 23: 2991-98. http://dx.doi.org/10.1128/MCB.23.8.2991-2998.2003

[21] BASSI R, GIUSSANI P, ANELLI V, COLLEONI T, PEDRAZZI $\mathrm{M}$, et al. HMGB1 as an autocrine stimulus in human T98G glioblastoma cells: role in cell growth and migration. J Neurooncol 2008; 87: 23-33. http://dx.doi.org/10.1007/ s11060-007-9488-y

[22] KAWAHARA N, TANAKA T, YOKOMIZO A, NANRI H, ONO M, et al. Enhanced coexpression of thioredoxin and high mobility group protein 1 genes in human hepatocellular carcinoma and the possible association with decreased sensitivity to cisplatin. Cancer Res 1996; 56: 5330-33.

[23] VOLP K, BREZNICEANU ML, BOSSER S, BRABLETZ T, KIRCHNER T, et al. Increased expression of high mobility group box 1 (HMGB1) is associated with an elevated level of the antiapoptotic c-IAP2 protein in human colon carcinomas. Gut 2006; 55: 234-42. http://dx.doi.org/10.1136/ gut.2004.062729

[24] ITO N, DEMARCO RA, MAILLIARD RB, HAN J, RABINOWICH H, et al. Cytolytic cells induce HMGB1 release from melanoma cell lines. J Leukoc Biol 2007; 81: 75-83. http://dx.doi.org/10.1189/jlb.0306169

[25] UGRINOVA I, PASHEV IG, PASHEVA EA. Nucleosome binding properties and Co-remodeling activities of native and in vivo acetylated HMGB-1 and HMGB-2 proteins. Biochemistry-Us 2009; 48: 6502-07. http://dx.doi.org/ 10.1021/bi9004304

[26] PASHEVA E, SAROV M, BIDJEKOV K, UGRINOVA I, SARG $B$, et al. In vitro acetylation of HMGB-1 and -2 proteins by CBP: the role of the acidic tail. Biochemistry-Us 2004; 43: 2935-40. http://dx.doi.org/10.1021/bi035615y

[27] EVANKOVICH J, CHO SW, ZHANG R, CARDINAL J, DHUPAR R, et al. High mobility group box 1 release from hepatocytes during ischemia and reperfusion injury is mediated by decreased histone deacetylase activity. J Biol Chem 2010; 285: 39888-97. http://dx.doi.org/10.1074/jbc.M110.128348

[28] YANG H, ANTOINE DJ, ANDERSSON U, TRACEY KJ. The many faces of HMGB1: molecular structure-functional activity in inflammation, apoptosis, and chemotaxis. J Leukoc Biol 2013; 93: 865-73. http://dx.doi.org/10.1189/jlb.1212662 
[29] TAGUCHI A, BLOOD DC, DEL TG, CANET A, LEE DC, et al. Blockade of RAGE-amphoterin signalling suppresses tumour growth and metastases. Nature 2000; 405: 354-60. http://dx.doi.org/10.1038/35012626

[30] LOTZE MT, DEMARCO RA. Dealing with death: HMGB1 as a novel target for cancer therapy. Curr Opin Investig Drugs 2003; 4: 1405-09.

[31] DUMITRIU IE, BARUAH P, MANFREDI AA, BIANCHI ME, ROVERE-QUERINI P. HMGB1: guiding immunity from within. Trends Immunol 2005; 26: 381-87. http://dx.doi. org/10.1016/j.it.2005.04.009
[32] TAFANI M, SCHITO L, PELLEGRINI L, VILLANOVA L, MARFE G, et al. Hypoxia-increased RAGE and P2X7R expression regulates tumor cell invasion through phosphorylation of Erk1/2 and Akt and nuclear translocation of NF-\{kappa\}B. Carcinogenesis 2011; 32: 1167-75. http://dx.doi.org/10.1093/ carcin/bgr101

[33] MIGNOGNA MD, FEDELE S, LO RL, LO ML, BUCCI E. Immune activation and chronic inflammation as the cause of malignancy in oral lichen planus: is there any evidence? Oral Oncol 2004; 40: 120-30. http://dx.doi.org/10.1016/ j.oraloncology.2003.08.001 